\title{
Strength Study Of Tyre Rubber Concrete
}

\author{
Sulagno Banerjee ${ }^{1}$, Dr. Jessyrooby ${ }^{2}$ \\ ${ }^{1}$ Assistant Professor, Civil Engineerieng Department, Elitte College Of Engineering, Sodepur, Kolkata, India \\ ${ }^{2}$ Professor, Civil Engineering Department, Hindustan University, Padur, Chennai, Tamil Nadu, India \\ Email: connect2sulagno@ rediffmail.com, jessyrooby@gmail.com
}

\begin{abstract}
Due to the rapid growth in automobile industry, use of tyre is increasing day to day and there is no reuse of the same to decrease the environmental pollution. The disposal of waste tyres is facing major problems in India. The growing problem of waste tyre disposal in India can be alleviated if new recycling routes can be found for the surplus tyres. It is estimated that 1.2 billions of waste tyre rubber produced globally in a year. It is estimated that $11 \%$ of postconsumer tyres are exported and $27 \%$ are sent to landfill, stockpiled or dumped illegally and only $4 \%$ is used for civil engineering projects. Hence efforts have been taken to identify the potential application of waste tyres in civil engineering projects. In this present study, cubes are casted of M25 grade by replacing $5,10,15$ percent of tyre rubber aggregate with coarse aggregate and compared with regular M25 grade concrete. Properties of fresh concrete like workability, compressive strength,split tensile strength,flexural strength of hardened concrete were identified. The aim is to investigate the optimal use of waste tyre rubber as coarse aggregate in concrete composite.
\end{abstract}

Keywords: "Tyre", "Rubberized Concrete", "Replacement of coarse aggregate by used rubber", "Waste material", "Rubber Aggregates".

\section{INTRODUCTION:}

In a fast developing country like India there is increase in urbanization resulting increase in plying of vehicles to a great extent. With the increase of vehicles the quantum of used and rejected tyres is also being increased. These wastes and rejected tyres badly affect the environment. For the benefit of the society particularly to have the better environment these waste tyres can be utilized into concrete construction. It is the primary aim of our study to introduce a new Technology which will be beneficial to environment. Through this study we are going to find out the suitable proportion and percentage of mixing the recycled coarse rubber aggregates obtained from waste tyres with the locally available materials required for concrete. For this purpose, there is a number of laboratory tests on prepared specimens and the results so obtained have been analysed suitably.

\section{OBJECTIVE \& PAST RESEARCH}

Concrete, the ingredients of which are cement,steel, aggregates (sand, stone-chips) is the most important material in construction work. Hence, there is a high demand for those materials in the commercial sector. It is known fact that in general aggregates used in concrete are obtained by mining. Unfortunately mining causes severe environmental damages by lowering the ground water table.It also disintegrates rock strata which is mainly responsible for earthquake as well as land slide. Engineers are certainly trying to figure out an alternative materials as a solution of the aforesaid problem. Number of researchers have conducted to find out the alternative use of the above traditional materials. Emiroglu et al [1] found that Slump depends on rubber content and there is a gradual decrease in strength with the increase of rubber. Gammel et al [2] tested concrete with $10 \%-25 \%$ crumb rubber replacement along with Silica fume and Rubcrete. Sali Tayeh et al [3] found satisfactory performance against impact load and bending load with increased in percentage of sand replacement by the crumb rubber. Helme et al [4] recommended 25\% Substitution showed compressive strength within allowable range for most applications of concrete of the control mix design. Naito et al [5] found unit weight of C R C decreases linearly. Richardson et al [6] found Concrete strength reduction is an indication of air void / crumb spacing which offers freeze / thaw protection. Richardson et al [7] concluded addition of $0.5 \%$ and $1 \%$ rubber crumb by mass of concrete to replicate levels of air entrainment that will provide freeze than durability. Naik et al [8] found that it is possible to make relatively high strength rubber concrete using magnesium oxy chloride cement, which gives better bonding characteristics to rubber and significantly improves the performance of rubcrete. Senthilet al [9] found grade of concrete plays the major role in the ductility performance of rubber replaced concrete.

\section{EXPERIMENTAL INVESTIGATION 3.1 Materials Used}

3.1.1Cement and Aggregates

In the present study Ordinary Portland Cement of grade 43, confirming to IS: 8112 1989[10] was used for preparing the concrete. The specific gravity of cement was 3.15 . Fine aggregate- Natural River sand passing through $4.75 \mathrm{~mm}$ IS sieve is used for making concrete. As per IS: $383-1970[11]$ natural river sand was categorized under grading zone I. The specific gravity and fineness modulus of sand is found to be 2.65 and 3.05. Coarse aggregate Coarse aggregate was passed through $80 \mathrm{~mm}$ sieve and retained on $4.75 \mathrm{~mm}$ sieve confirming IS: $383-$ 
1970[11] was used for concreting. The specific gravity and fineness modulus of coarse aggregate is found to be 2.695 and 7.7 .

\subsubsection{Water}

Clean portable water free from suspended particles, chemical substances, biological elements etc., is used both for mixing of concrete and curing.

\subsubsection{Rubber aggregate}

This study has concentrated on the performance of a single gradation of rubber prepared by manual cutting (Pic1). The maximum size of the rubber aggregate was 40 $\mathrm{mm}$. The properties of the rubber used as aggregate is given below in Table1:

\begin{tabular}{|l|l|l|}
\hline PARAMETERS & UNIT & $\begin{array}{l}\text { STANDARD } \\
\text { SPECS }\end{array}$ \\
\hline $\begin{array}{l}\text { ACETONE } \\
\text { EXTRACTION }\end{array}$ & $\%$ & $\mathbf{5 - 1 0}$ \\
\hline $\begin{array}{l}\text { ASH } \\
\text { CONTETNT }\end{array}$ & $\%$ & 4 Max \\
\hline $\begin{array}{l}\text { BULK } \\
\text { DENSITY }\end{array}$ & $\begin{array}{l}\text { gm } \\
\text { cc }\end{array}$ & $\mathbf{0 . 3 0}-\mathbf{0 . 4 5}$ \\
\hline $\begin{array}{l}\text { SIEVE } \\
\text { ANALYSIS } \\
\text { PASSING } \\
\text { MM SIEVE }\end{array}$ & $\%$ & $\mathbf{9 9}$ \\
\hline $\begin{array}{l}\text { SIEVE } \\
\text { ANALYSIS } \\
\text { PASSING } \\
\text { MM SIEVE }\end{array}$ & $\%$ & $\mathbf{1}$ \\
\hline
\end{tabular}

Table 1 Rubber Properties

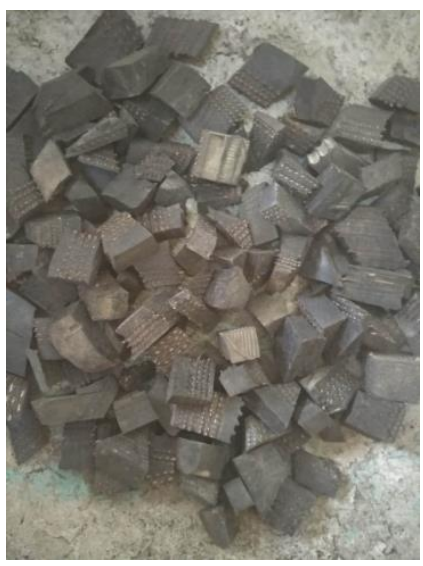

PiclRubber aggregate

\section{MIX DESIGN (AS PER IS 10262 - 2009)}

Based on the trial mixes the final design mix was prepared for M25 grade of concrete as per IS 10262:2009[12]. The concrete mix proportions were shown in Table 2

\begin{tabular}{|l|l|l|l|}
\hline $\begin{array}{l}\text { Grade of } \\
\text { concrete }\end{array}$ & $\begin{array}{l}\text { Target mean } \\
\text { strength } \\
\left(\mathbf{N} / \mathbf{m m}^{2}\right)\end{array}$ & $\begin{array}{l}\text { W/C } \\
\text { ratio }\end{array}$ & $\begin{array}{l}\text { Mix } \\
\text { Proportion }\end{array}$ \\
\hline M 25 & $\mathbf{3 1 . 6 0}$ & $\mathbf{0 . 4 5}$ & $\mathbf{1 : 2 . 2 : 2 . 7 2}$ \\
\hline
\end{tabular}

\section{PREPARATION SPECIMENS}

Standard steel moulds were used for casting cubes of size $150 \mathrm{~mm} \times 150 \mathrm{~mm} \times 150 \mathrm{~mm}$. The details of the test specimens are shown in Table 3.

\begin{tabular}{|c|c|c|c|c|c|c|}
\hline $\begin{array}{l}\text { Mark } \\
\text { ing }\end{array}$ & $\begin{array}{l}\% \text { of } \\
\text { repl } \\
\text { ace } \\
\text { men } \\
t\end{array}$ & $\begin{array}{l}\text { Wate } \\
\mathbf{r} \\
(\mathrm{kg})\end{array}$ & $\begin{array}{l}\text { Ce } \\
\text { me } \\
\text { nt } \\
(\mathrm{kg})\end{array}$ & $\begin{array}{l}\text { C.A } \\
(\mathbf{k g})\end{array}$ & $\begin{array}{l}\text { F. } \\
\text { A } \\
(\mathbf{k g} \\
)\end{array}$ & $\begin{array}{l}\text { Rub } \\
\text { ber( } \\
\text { kg) }\end{array}$ \\
\hline SC & 0 & 2.52 & 5.6 & $\begin{array}{l}15.1 \\
2\end{array}$ & $\begin{array}{l}6.7 \\
2 \\
\end{array}$ & 0 \\
\hline SCR5 & 5 & 2.52 & 5.6 & $\begin{array}{l}14.3 \\
6\end{array}$ & $\begin{array}{l}6.7 \\
2\end{array}$ & 0.76 \\
\hline $\begin{array}{l}\text { SCR1 } \\
0 \\
\text { SCR1 } \\
5\end{array}$ & 15 & $\begin{array}{l}2.52 \\
2.52\end{array}$ & $\begin{array}{l}5.6 \\
5.6\end{array}$ & $\begin{array}{l}13.6 \\
0 \\
13.1 \\
8 \\
\end{array}$ & $\begin{array}{l}6.7 \\
2 \\
6.7 \\
2 \\
\end{array}$ & $\begin{array}{l}1.52 \\
2.34\end{array}$ \\
\hline
\end{tabular}

Table 3 Details of cube specimen

\section{TESTS FOR PROPERTIES}

The compression test,split tensile strength,flexural strength, workability test were carried out to determine the strength and workability.

\subsection{Workability Test}

For workability, slump test and compaction factor for the concrete was found out and it is tabulated below in Table 4. Slump test was conducted using Slump cone apparatus to determine the workability and it is shown in Pic2. The variation of slump with different percentages of rubber is shown in Figure1 and the variation of Compaction factor with different percentages of rubber is shown in Figure2.
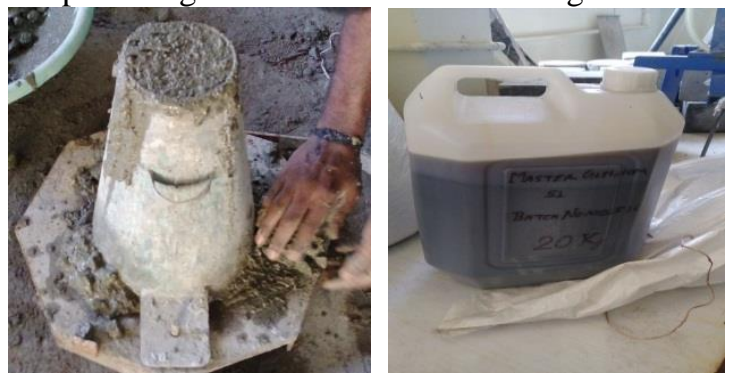

Pic 2 Slump test and glenium

\begin{tabular}{|l|l|l|l|}
\hline specimen & $\begin{array}{l}\text { \% of } \\
\text { rubber } \\
\text { aggregate } \\
\text { replaced }\end{array}$ & $\begin{array}{l}\text { Slump } \\
\text { value } \\
(\mathbf{m m})\end{array}$ & $\begin{array}{l}\text { Compacting } \\
\text { factor }\end{array}$ \\
\hline SC & $\mathbf{0}$ & $\mathbf{8 0}$ & $\mathbf{0 . 8 4}$ \\
\hline SCR5 & $\mathbf{5}$ & $\mathbf{6 0}$ & $\mathbf{0 . 7 6}$ \\
\hline SCR10 & $\mathbf{1 0}$ & $\mathbf{0}$ & $\mathbf{0 . 7 0}$ \\
\hline SCR15 & $\mathbf{1 5}$ & $\mathbf{0}$ & $\mathbf{0 . 7 0}$ \\
\hline
\end{tabular}

Table 4 Result of workability test (without admixture)

Table 2 Mix proportions 
International Journal of Research in Advent Technology, Vol.7, No.4, April 2019

E-ISSN: 2321-9637

Available online at www.ijrat.org

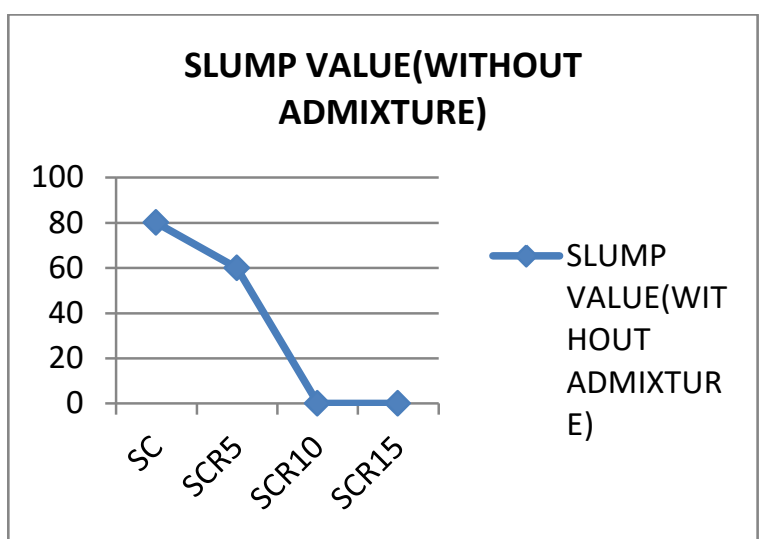

Figure 1

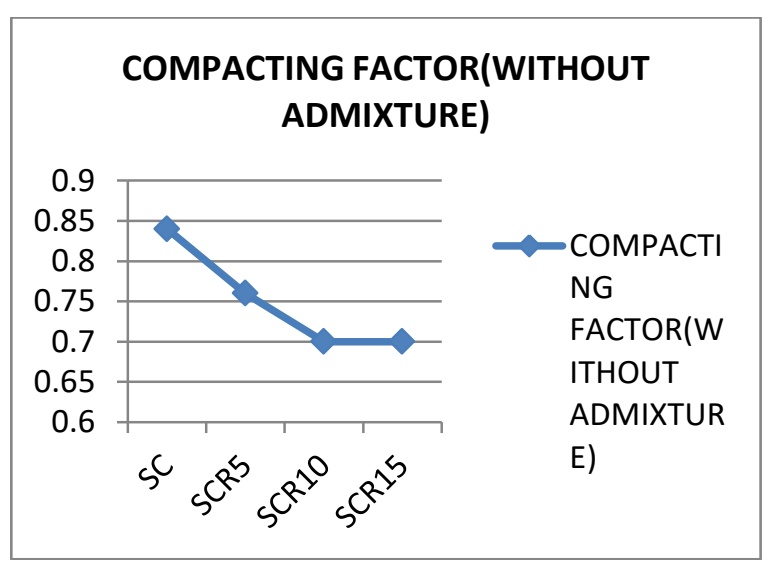

Figure 2

The replacement of coarse aggregate by scrap tyre rubber effects on the workability of the concrete. The workability of rubberized concrete shows a decrease in workability with increase of rubber. To increase the workability we use Glenium super-plasticizer (Pic2) as $0.5 \%$ of cement in rubber concrete. The result and differences are shown in table 5 and fig $3,4,5 \& 6$.

\begin{tabular}{|l|l|l|l|}
\hline specimen & $\begin{array}{l}\text { \% of } \\
\text { rubber } \\
\text { aggregate } \\
\text { replaced }\end{array}$ & $\begin{array}{l}\text { Slump } \\
\text { value } \\
(\mathbf{m m})\end{array}$ & $\begin{array}{l}\text { Compacting } \\
\text { factor }\end{array}$ \\
\hline SC & $\mathbf{0}$ & $\mathbf{1 0 0}$ & $\mathbf{0 . 8 9}$ \\
\hline SCR5 & $\mathbf{5}$ & $\mathbf{9 0}$ & $\mathbf{0 . 8 6}$ \\
\hline SCR10 & $\mathbf{1 0}$ & $\mathbf{7 2}$ & $\mathbf{0 . 8 0}$ \\
\hline SCR15 & $\mathbf{1 5}$ & $\mathbf{6 8}$ & $\mathbf{0 . 7 8}$ \\
\hline
\end{tabular}

Table 5 Result of workability test (with admixture)

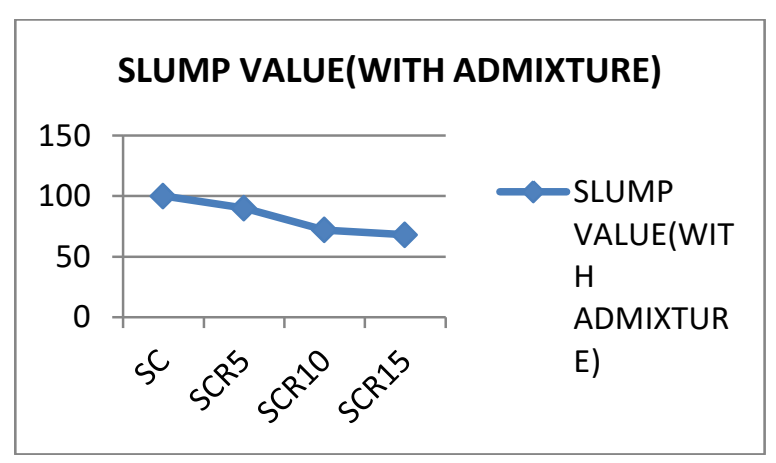

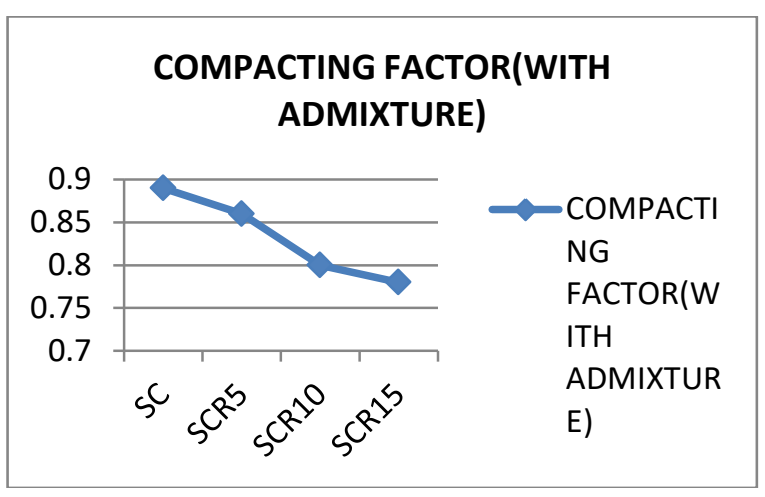

Figure 4

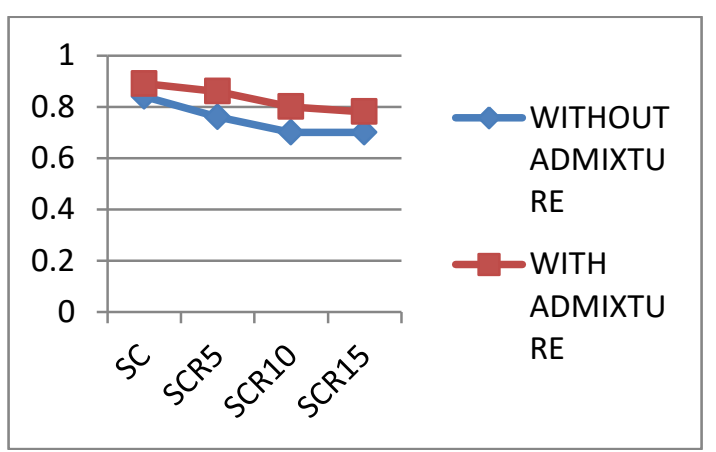

Figure 5(compaction factor)

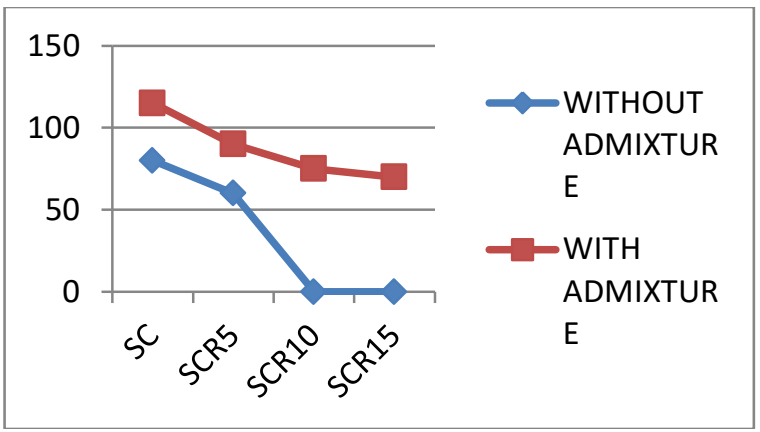

Figure 6(slump value)

\subsection{Compressive strength}

The compressive strength of the specimens was determined in a universal testing machine of 200 tones capacity (Pic.4) and it is tabulated below in Table6 \& Table7 \&fig 7.The failure pattern of the cube is shown in Pic. 3

\begin{tabular}{|l|l|l|l|}
\hline specimen & $\begin{array}{l}\text { \% of } \\
\text { rubber } \\
\text { aggregate } \\
\text { replaced }\end{array}$ & $\begin{array}{l}7 \text { days } \\
\text { strength } \\
\text { (mpa) }\end{array}$ & $\begin{array}{l}\text { 28 days } \\
\text { strength } \\
\text { (mpa) }\end{array}$ \\
\hline SC & 0 & 20.0 & 30.90 \\
\hline SCR5 & 5 & 16.8 & 28.5 \\
\hline SCR10 & 10 & 15.0 & 23.8 \\
\hline SCR15 & 15 & 12.6 & 19.1 \\
\hline
\end{tabular}

Table 6 Compressive strength (without admixture) 
International Journal of Research in Advent Technology, Vol.7, No.4, April 2019

E-ISSN: 2321-9637

Available online at www.ijrat.org

\begin{tabular}{|l|l|l|l|}
\hline specimen & $\begin{array}{l}\text { \% of days } \\
\text { rubber } \\
\text { aggregate } \\
\text { replaced }\end{array}$ & $\begin{array}{l}\mathbf{7} \text { days } \\
\text { strength } \\
\text { (mpa) }\end{array}$ & $\begin{array}{l}\text { 28 } \\
\text { strength } \\
\text { (mpa) }\end{array}$ \\
\hline SC & 0 & 21.2 & 32.31 \\
\hline SCR5 & 5 & 17.7 & 29.35 \\
\hline SCR10 & 10 & 15.4 & $\mathbf{2 4 . 7 0}$ \\
\hline SCR15 & 15 & 13.1 & $\mathbf{2 0 . 0 0}$ \\
\hline
\end{tabular}

Table 7 Compressive strength (with admixture)

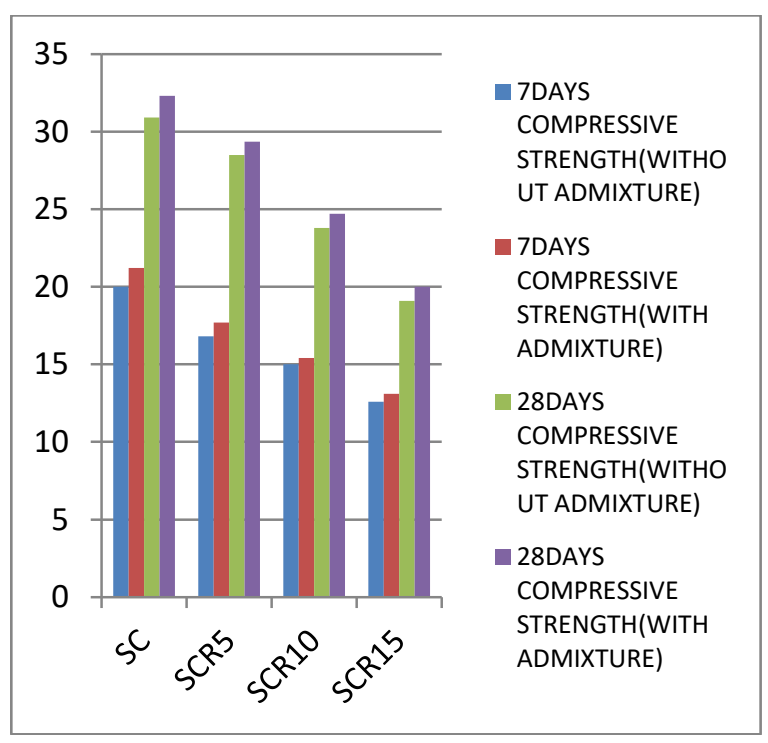

Figure 7(compressive strength)
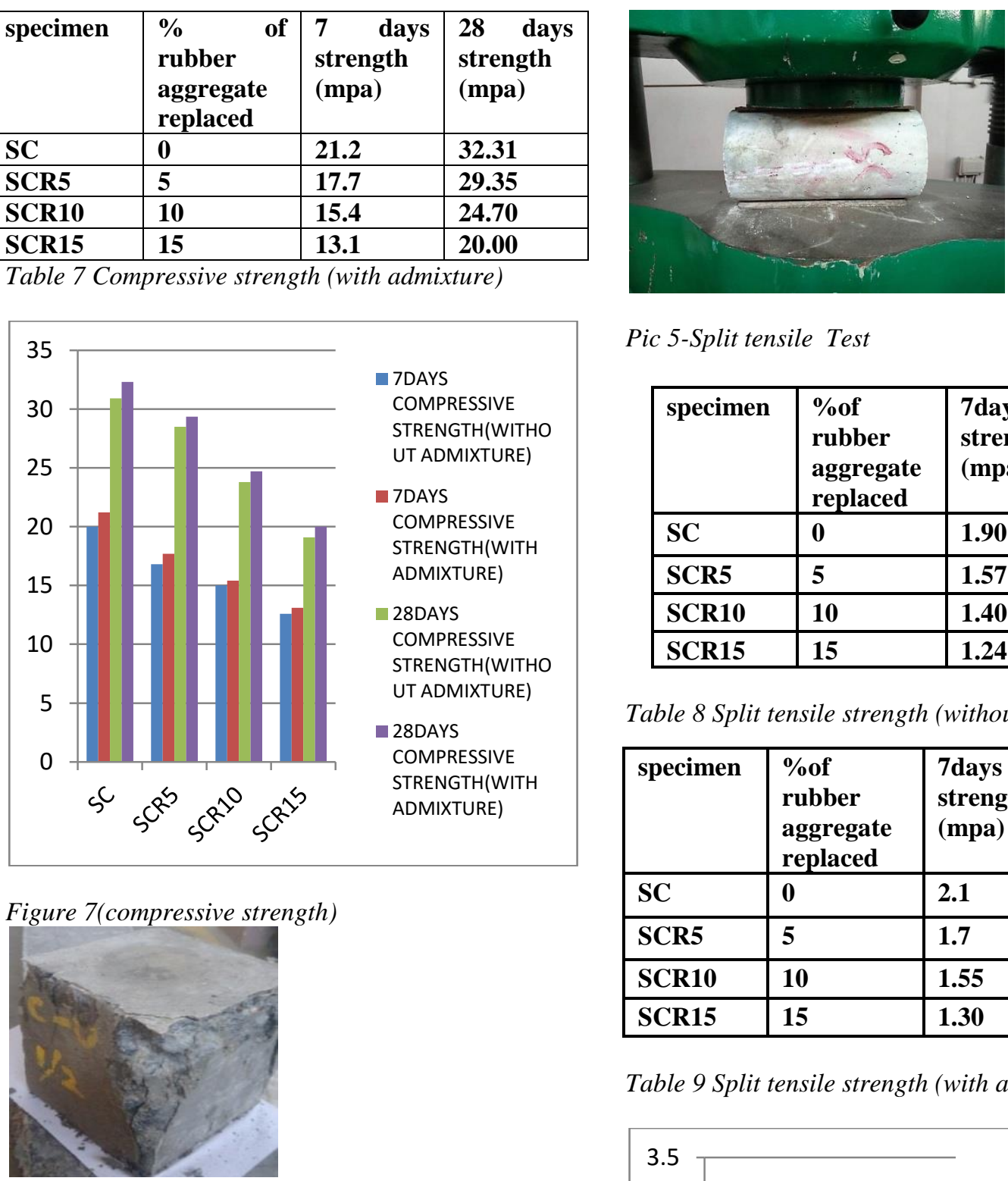

Pic 5-Split tensile Test

\begin{tabular}{|l|l|l|l|}
\hline specimen & $\begin{array}{l}\text { \%of } \\
\text { rubber } \\
\text { aggregate } \\
\text { replaced }\end{array}$ & $\begin{array}{l}\text { 7days } \\
\text { strength } \\
\text { (mpa) }\end{array}$ & $\begin{array}{l}\text { 28days } \\
\text { strength } \\
\text { (mpa) }\end{array}$ \\
\hline SC & 0 & 1.90 & 2.95 \\
\hline SCR5 & 5 & 1.57 & 2.74 \\
\hline SCR10 & 10 & 1.40 & 2.20 \\
\hline SCR15 & 15 & 1.24 & 1.95 \\
\hline
\end{tabular}

Table 8 Split tensile strength (without admixture)

\begin{tabular}{|l|l|l|l|}
\hline specimen & $\begin{array}{l}\text { \%of } \\
\text { rubber } \\
\text { aggregate } \\
\text { replaced }\end{array}$ & $\begin{array}{l}\text { 7days } \\
\text { strength } \\
\text { (mpa) }\end{array}$ & $\begin{array}{l}\text { 28days } \\
\text { strength } \\
\text { (mpa) }\end{array}$ \\
\hline SC & 0 & 2.1 & 3.2 \\
\hline SCR5 & 5 & 1.7 & 2.9 \\
\hline SCR10 & 10 & 1.55 & 2.5 \\
\hline SCR15 & 15 & 1.30 & 2.15 \\
\hline
\end{tabular}

Table 9 Split tensile strength (with admixture)

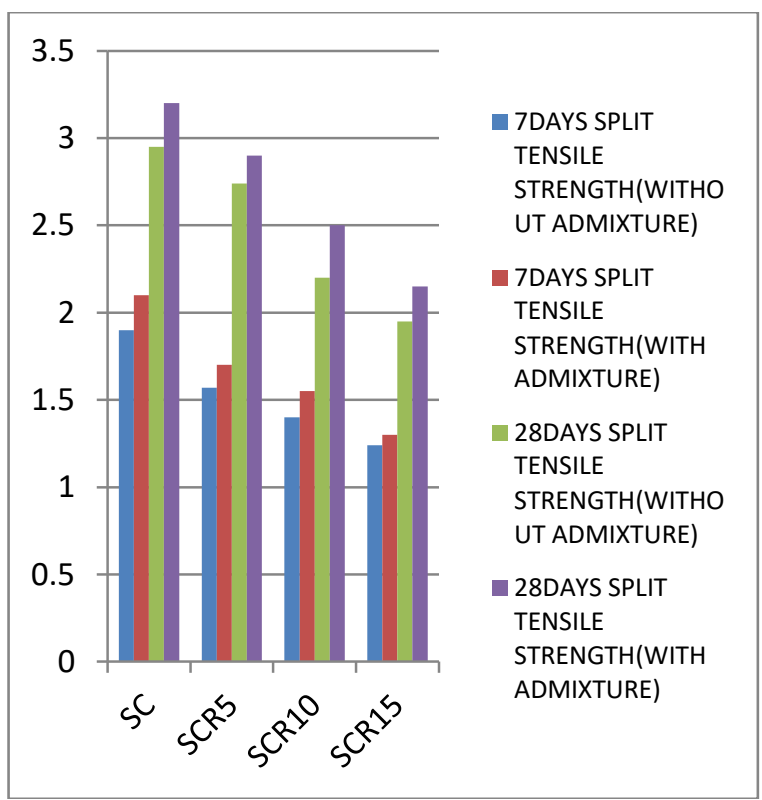

Figure 8(split tensile strength) 


\subsection{Flexural strength}

The flexural strength of the specimens was determined in a flexural testing machine (Pic.6) and it is tabulated below in Table10 \& Table11 and the variation is shown in fig 9 .

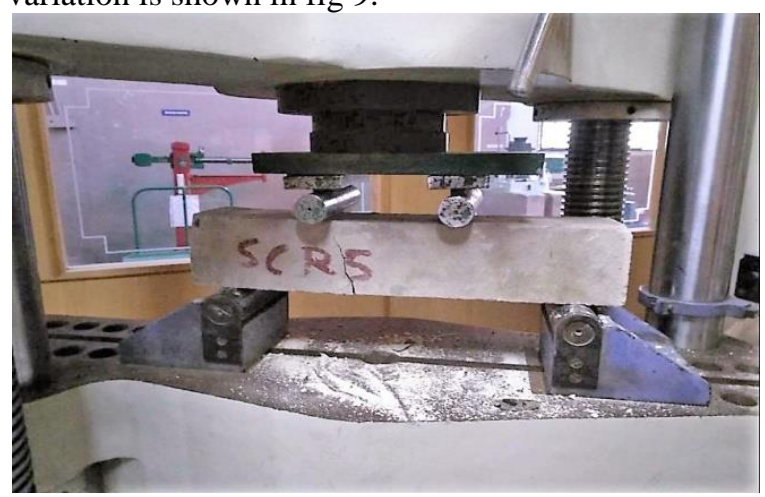

Pic 6-Flexural Test

Table 10 Flexural strength (without admixture)

\begin{tabular}{|l|l|l|l|}
\hline specimen & $\begin{array}{l}\text { \% of rubber } \\
\text { aggregate } \\
\text { replaced }\end{array}$ & $\begin{array}{l}\text { 7days } \\
\text { strength } \\
\text { (mpa) }\end{array}$ & $\begin{array}{l}\text { 28 days } \\
\text { strength } \\
\text { (mpa) }\end{array}$ \\
\hline SC & 0 & 3.10 & 4.85 \\
\hline SCR5 & 5 & 2.69 & 4.50 \\
\hline SCR10 & 10 & 2.42 & 3.78 \\
\hline SCR15 & 15 & 2.10 & 3.10 \\
\hline
\end{tabular}

Table 11 Flexural strength (with admixture)

\begin{tabular}{|l|l|l|l|}
\hline specimen & $\begin{array}{l}\text { \%of } \\
\text { rubber } \\
\text { aggregate } \\
\text { replaced }\end{array}$ & $\begin{array}{l}\text { 7days } \\
\text { strength } \\
\text { (mpa) }\end{array}$ & $\begin{array}{l}\text { 28 days } \\
\text { strength } \\
\text { (mpa) }\end{array}$ \\
\hline SC & 0 & 3.40 & 5.10 \\
\hline SCR5 & 5 & 2.85 & 4.72 \\
\hline SCR10 & 10 & 2.50 & 3.95 \\
\hline SCR15 & 15 & 2.15 & 3.25 \\
\hline
\end{tabular}

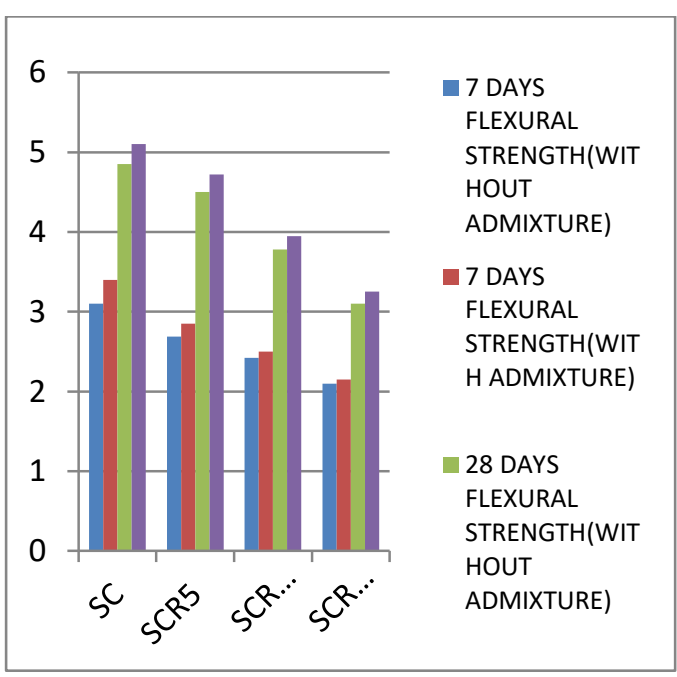

Figure 9(flexural strength)

\section{CONCLUSIONS}

It is observed that the compressive strength, split tensile strength as well as the flexural strength decreases as the addition of percentage of rubber increases.

$5 \& 10$ percent replacement of rubber aggregate may achieve the compressive strength as that of the normal concrete with some few alterations like adding extra silica or by replacing cement with more fine particles such as GGBS. slightly.

Adding admixture can increase the strengths

It can be concluded that despite the reduced compressive strength of rubberized concrete in comparison to conventional concrete, there is a potential large market for concrete products in which inclusion of rubber aggregates would be feasible which will utilize the discarded rubber tyres, the disposal of which is a big problem for environment pollution.

It is recommended to replace $5-10 \%$ of waste tyre rubber aggregate with coarse aggregate, which will be the optimum replacement in concrete composites.

\section{CONFLICTS OF INTEREST}

On behalf of all authors, the corresponding author states that there is no conflict of interest.

\section{DATA AVAILABILITY}

The data used to support the findings of this study are available from the corresponding author upon request.

\section{REFERENCE}

[1] M. Emiroglu.S. Yildiz O Kestemur.M.H. Kelestemur, "Bond performance of rubber particles in the self-compacting concrete" ISBN: 978 - 88 - $907078-3-42012$ Publisher creations

[2] EL Gammel,A-K Abdel, Gawad,Y- EL Sherbini,A. Shalaby,"Compressive strength of concrete utilising waste tire rubber". Journal of Emerging Trends in Engineering and Applied Sciences (JETEAS) 1 (1): 96-99

[3] Ali Tayeh,"Effect of replacement of sand by waste ".Civil and Environmental Research ISSN 2224-5790 (Paper) ISSN 2225-0514 (Online) Vol.3, No.13, 2013

[4] Jenna Lee Helme, "Concrete, A use for use Tires " cssf projects 2010

[5] Clay Naito,,M. Asce,,Joe states, Christopher Jackson,,Bryan Bewick. “Assessment of crumb Rubber concrete for flexural structural member". AESC, Journal of civil engineering vol 26 issue 10

[6] Alan Richard son ,Kathryn Coventry,JacquesPienaan, "The potential for achieving freeze/thaw protection in concrete through addition of rubber crum" Paper's No. BUE-FISC - 2 . 
[7] A. Richardson,K. Coventry,U. Dave,J. Piemar, "Freeze / thaw performance of concrete using granulated rubber crumb".journal of green building vol 6 november 10 .

[8] Tarun Naik, Rafat Siddique,'Properties of concrete containing scrap tire rubber - an overview". Report No. CBU-2002-06 REP-459 February 2002, centre for bi product utilization

[9] Senthil Vadivel, R. Thennozhi,'Experimental study on waste tyre rubber replaced concreteecofriendly construction materials". Journal of Applied Sciences Research;Jun2012, p3966

[10] IS, 8112-1989 Indian Standard,of OPC 43 BIS, New Delhi

[11] IS383-1970 , Indian Standard of aggregate, BIS, New Delhi

[12] IS 10262-2009 Indian Standard of concrete mix design, BIS, New Delhi

[13] IS, IS 516:1959 Indian Standard of strength test, BIS, New Delhi

[14] IS 1199-1959, Indian Standard of workability test , BIS New Delhi 